\title{
Maatalousyrittäjän vuosikello - apuväline maatalousyrityksen johtamiseen
}

\author{
Eerikki Kaila $^{1)}$ ja Janne Karttunen ${ }^{1)}$ \\ ${ }^{1)}$ TTS - Työtehoseura,PL 5,05201 Rajamäki,eerikki.kaila@tts.fi, janne.karttunen@tts.fi
}

\section{Tiivistelmä}

Maatalousyrityksen johtamiseen liittyy lukuisia tietyin väliajoin tai epäsäännöllisesti toistuvia tehtäviä, tapahtumia ja määräpäiviä, joiden hallinta ja organisointi tukevat maatalousyrittäjän ja koko yrittäjäperheen hyvinvointia. Näiden asioiden hallinta vaikuttaa niin yrityksen taloudelliseen tulokseen kuin yrittäjän työtaakkaan ja jaksamiseen. Suoraan rahallista menetystä tulee esimerkiksi maataloustukien haun myöhästymisestä. Välillisesti taloudellista menetystä tulee muun muassa töiden viivästymisestä. Tietyt tapahtumat, kuten koneurakoitsijan tai lomittajan tilaaminen, on syytä ennakoida hyvissä ajoin. Samoin tapahtumista on opittava seuraavaa kertaa varten.

Maatalousyrittäjien mukaan erityisesti harvemmin kuin viikoittain toistuvat tapahtumat vaativat apuvälineitä muistamiseen. Tiettyyn viikonpäivään sidotut viikoittaiset tapahtumat pysyvät sen sijaan hyvin mielessä. Samoin tärkeimmät vuosittain tiettyyn ajankohtaan toistuvat tehtävät, kuten veroilmoituksen jättö, jäävät yleensä hyvin mieleen.

Maatalousyrityksen johtaminen vaatii taitoja, joista monet opitaan vasta maatilaa itse johdettaessa. Tämän takia johtamisen apuvälineitä tarvitsevat erityisesti nuoremmat viljelijät, joilla ei ole vielä vahvaa rutiinia asioiden hallinnasta. Maatalousyrityksen tuotantosuunta, koko ja yrittäjän arvot sekä toimintatavat vaikuttavat apuvälineen sisältöön ja siltä vaadittaviin toimintoihin.

Asioiden hallintaan ja muistamiseen voidaan käyttää useita eri apuvälineitä ja keinoja. Tilanteesta ja henkilöstä riippuu, mikä apuväline on kulloinkin sopivin. Painetut kalenterit ovat perinteisiä arjen hallinnassa käytettyjä apuvälineitä. Kännykät ovat käteviä työkaluja muistuttamaan tapahtumista ja merkittäessä muistiinpanoja. ATK-pohjaisia ajanhallintaan liittyviä sovelluksia on sekä maksullisia että vapaasti netistä ladattavia. Näissä käyttöliittymä on yleensä englanninkielinen. Erityisesti maatalousyrityksen tarpeisiin laadittuja ajanhallintaohjelmia ei ole markkinoilla.

TTS - Työtehoseurassa on valmistunut maatilatalouden kehittämisrahaston rahoittama ja yhteistyössä Savonia AMK:n kanssa toteutettu hanke, jossa laadittiin maatalousyrityksen johtamiseen ja töiden organisointiin liittyvää päätöksentekoa tukeva atk-pohjainen sovellus: maatalousyrittäjän vuosikello. Vuosikellon avulla maatalousyrittäjä kykenee ennakoimaan ja varaamaan aikaa vuosittain toistuviin töihin ja tapahtumiin.

Maatalousyrittäjän vuosikello toimii uusimmissa Excel-versioissa. Sovellus sisältää yksityiskohtaiset käyttöohjeet sekä runsaasti eri tuotantosuuntien tiloille soveltuvia tehtäviä ja tapahtumia, joista käyttäjä voi valita tarpeellisiksi katsomansa tai lisätä uusia. Sovellus on vapaasti ladattavissa TTS:n nettisivuilta.

Vuosikellon pääkomponentteja ovat kuukausikalenterit, jotka vastaavat Excel-tiedoston tauluja. Vuosikello sisältää valmiiksi kuukausikalenterit vuosille 2011-2016. Käyttäjä pystyy omatoimisesti lisäämään kuukausikalentereita sovellukseen ja pidentämään näin sen käyttöikää. Kuukausikalentereiden lisäksi sovellus sisältää vuosikello-näkymän, johon on sijoitettu tärkeimpiä maatilan johtamiseen liittyviä vuosittaisia tapahtumia kuukausijaolla.

Asiasanat: töiden organisointi, vuosikello, johtaminen, jaksaminen, atk-sovellus 


\section{Johdanto}

Tuotantoaan kehittävät maatalousyrittäjät tyypillisesti joko laajentavat perustuotantoaan tai monialaistavat tuotantoaan perusmaatalouden ulkopuolelle. Tilakoon kasvaessa samoin kuin tuotannon monialaistuessa töiden organisointi tulee entistä tärkeämmäksi ja haastavammaksi. Myös päätöksentekoon tarvitaan entistä enemmän aikaa.

Maatalousyrittäjien työssä jaksamista haittaavat eniten työn määrä, häiriöt työssä ja työvälineissä sekä oma terveydentila. Yli puolella vähintään 40 lypsylehmän maitotiloista työn suuri määrä on merkittävin jaksamista haittaava tekijä. Työn aikataulutus, suunnittelemattomuus ja työn laatu häiritsevät yli viidennestä isoista maitotiloista. (Suomen Gallup Elintarviketieto 2005).

Perustuotantoa laajennettaessa oma työpanos ja investoinnit kannattaa kohdistaa ensisijaisesti yrityksen ydintoimintoihin. Ydintoimintojen ulkopuolisia töitä voidaan ulkoistaa tai tehdä tilayhteistyönä tai oman työn ja edellä mainittujen keinojen yhdistelminä. Karttusen ja Tuuren (2008) mukaan noin 80 prosenttia keskikokoisista ja sitä suuremmista maatalousyrityksistä käyttää urakointipalveluita tai tekee tilayhteistyötä, kun metsätaloustöitä ei oteta huomioon.

Perustuotantotiloilla kuluu hallinnointi- ja johtamistöihin keskimäärin vajaa kolmannes maatalousyrittäjän kokonaistyöajasta, mutta vaihtelu on suurta eri tuotantosuunnissa (Tuure ym. 2008). Perustuotantotilojen ja monialaisten tilojen johtamisen tukemiseen tarvitaan kehittyneitä, helppokäyttöisiä ja muuhun tuotantotekniikkaan hyvin integroituvia johtamisen apuvälineitä. Näin voidaan paremmin vastata alati kasvaviin vaatimuksiin kustannustehokkaasta työn tuottavuuden nostamisesta sekä madaltaa tietokuormituksen ja päätöksenteon aiheuttamaa henkistä painetta. (Suutarinen ym. 2008).

Maatalousyrityksen johtamiseen liittyy lukuisia tietyin väliajoin tai epäsäännöllisesti toistuvia tehtäviä, tapahtumia ja määräpäiviä, jotka on organisoitava järkevästi. Näiden asioiden hallinta vaikuttaa niin yrityksen taloudelliseen tulokseen kuin yrittäjän ja koko yrittäjäperheen työmäärään ja hyvinvointiin.

Tämän tutkimuksen päätavoite oli edistää maatalousyrittäjien ruumiillista, henkistä ja taloudellista hyvinvointia. Tavoitteeseen pyrittiin laatimalla maatalousyrityksen johtamiseen ja töiden organisointiin liittyvää päätöksentekoa tukeva "maatalousyrittäjän vuosikello". Käytännön tavoitteena oli ohjata yrittäjää oppimaan kokemuksistaan ja jalkauttamaan tuotantostrategia luontaiseksi osaksi päivittäistä ja kausittaista töiden organisointia.

\section{Aineisto ja menetelmät}

Asioiden hallintaan ja muistamiseen voidaan käyttää useita eri apuvälineitä ja keinoja. Tilanteesta ja henkilöstä riippuu, mikä apuväline on kulloinkin sopivin. Painetut kalenterit ovat perinteisiä arjen hallinnassa käytettyjä apuvälineitä. Kännykät ovat käteviä työkaluja muistuttamaan tapahtumista ja merkittäessä muistiinpanoja.

Maatalousyrityksen suunnittelun ja johtamisen lähestulkoon välttämätön työkalu on nykyään tietokone. Ajanhallintaan liittyviä tietokonesovelluksia on sekä maksullisia että vapaasti netistä ladattavia tai suoraan netistä käsin käytettäviä. Näissä sovelluksissa käyttöliittymä ja -ohjeet ovat yleensä englanninkielisiä. Erityisesti maatalousyrityksen tarpeisiin laadittuja ajanhallintaohjelmia ei juurikaan ole markkinoilla. Tämän takia tässä hankkeessa päädyttiin laatimaan maatalousyrityksen tarpeisiin sopiva helppokäyttöinen atk-pohjainen työkalu.

Vuosikello-työkalua lähdettiin kehittämään MS Excel -taulukkolaskentaohjelmaan. Excel on monipuolinen sekä yleisesti tunnettu ja käytetty taulukkolaskentaohjelma. Tämä seikka madaltaa ainakin Exceliä aiemmin käyttäneiden kynnystä ottaa käyttöön kehitetty työkalu. Työkalun näkymien suunnittelussa ja toimintojen kehitystyössä käytiin läpi useita vaihtoehtoja. Haasteena oli erityisesti päivätason tarkkuuden esittäminen usean vuoden ajanjaksolla. Työkalun pääkomponentiksi valittiin kuukausikalenterit, joiden avulla käyttäjä pystyy parhaiten hallitsemaan töiden organisointiin ja päätöksentekoon liittyviä asioita. Kuukausikalenterit olivat myös helposti toteutettavissa Excelin taulukko-ominaisuuksin ja usean vuoden kuukausikalenterit saman Excel-tiedoston omina laskentatauluina.

Työkalun kuukausikalenterit tehtiin testausvaiheessa kolmivuotiseksi. Työkalun julkaisuversioon ajanjaksoksi valittiin viisi vuotta (2011-2015) eli työkalu sisältää 60 kuukausikalenteria. Tämän lisäksi käyttäjällä on mahdollisuus omatoimisesti lisätä kuukausikalentereita työkaluun. Työkaluun on kehitetty toiminto, joka laatii automaattisesti uuteen tauluun käyttäjän haluaman kuukausikalenterin. Kalenterinäkymä vastaa perinteistä seinäkalenteria (kuva 1). 


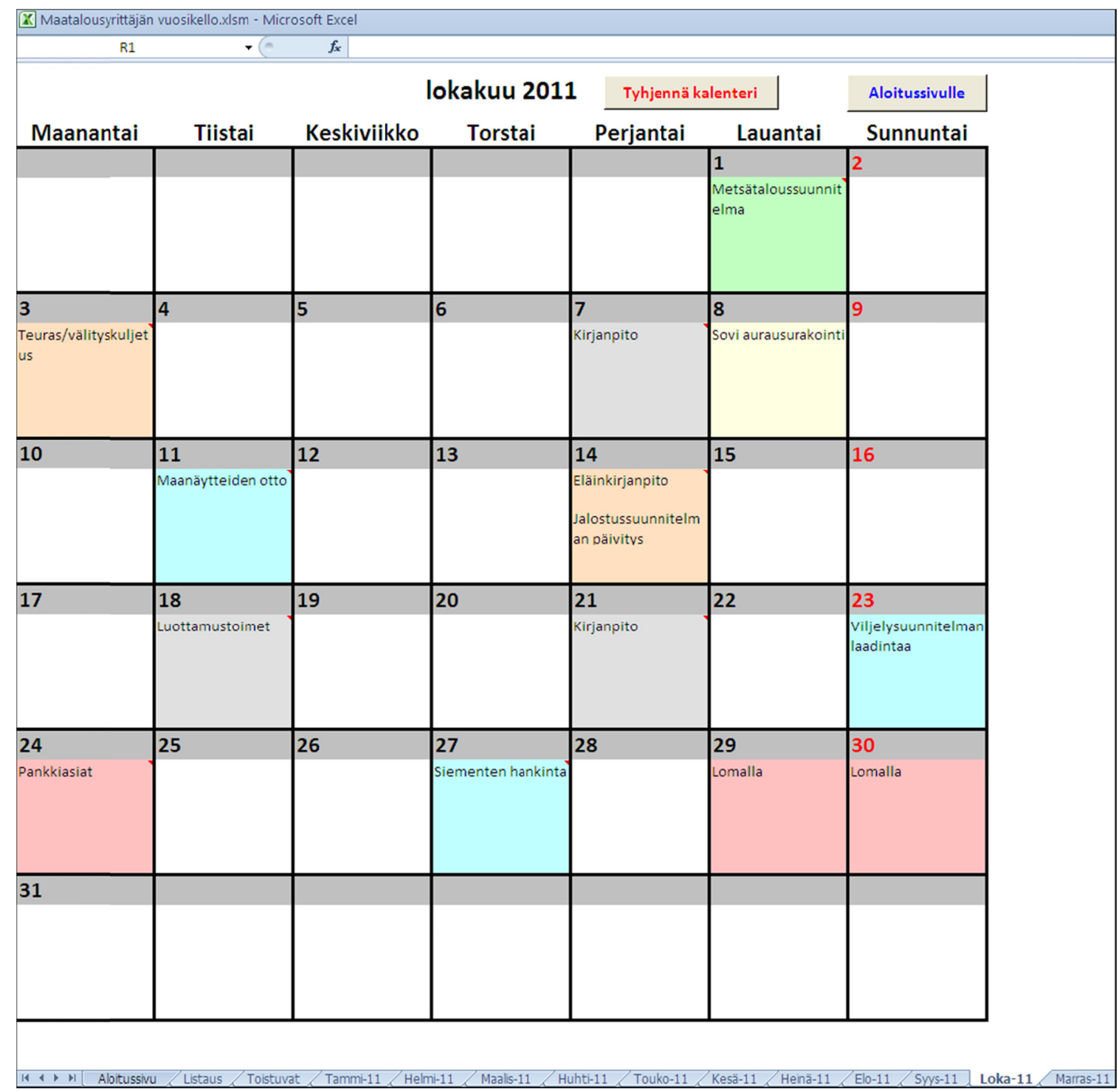

Kuva 1. Vuosikellon kuukausikalenterit muistuttavat paperisia seinäkalentereita. Työkalu sisältää laajan listauksen maatilan tehtävistä ja tapahtumista, joista käyttäjä voi valita tarpeelliseksi katsomansa tai lisätä omia tapahtumia kalenteriin. Tapahtumat on ryhmitelty kuuteen päätyöryhmään, jotka erottuvat kalenterissa eri väreinä. Tapahtumiin kirjatut lisätiedot näkyvät Excelin kommentteina.

Kuukausikalentereiden päiväkentät on jaettu kolmeen osaan, joten yhtä päivää kohti merkintöjä voi syöttää maksimissaan kolme. Mikäli kyseisessä päivässä on jo kolme merkintää, tapahtumien syöttötoiminto huomauttaa tästä käyttäjälle ja käyttäjän valinnasta riippuen joko sijoittaa merkinnän seuraavaan vapaaseen päivään tai peruttaa merkinnän syötön kuukausikalenteriin.

Tapahtumat on työkalussa ryhmitelty kuuteen pääryhmään: kasvintuotanto, kotieläintuotanto, metsätalous, muu yritystoiminta, suunnittelu ja johtaminen ja yksityistalous. Pääryhmään "suunnittelu ja johtaminen" sijoitetaan sellaiset maatilan johtamiseen liittyvät työt, jotka koskevat koko tilan yritystoimintaa. Muut hallinnointityöt sijoitetaan kunkin työn kohteen omaan päätyöryhmään, esimerkiksi kasvinviljelyyn liittyvät tukihakemukset päätyöryhmään "kasvintuotanto". Työkaluun on mahdollista syöttää yritystoiminnan lisäksi yksityistalouteen liittyviä tehtäviä ja tapahtumia. Näin yritystoiminnan ja yksityistalouden tärkeät tapahtumat ja tehtävät saadaan samaan näkymään ja kalenteriin, mikä osaltaan helpottaa maatalousyrittäjän arjen hallintaa ja jaksamista.

Ohjelma vaatii tietokoneelta toimiakseen MS Windows käyttöjärjestelmän ja MS Excel taulukkolaskentaohjelman (MS Office:n versiot 2003-2010). Työkalu on Excel-tiedosto, jonka voi vapaasti ladata TTS:n nettisivuilta omaan käyttöönsä. Koska pääosa työkalun toiminnoista on tehty MS Excel VBA -ohjelmoinnilla, työkalun käyttö edellyttää Excelissä makrojen käytön hyväksymisen. 


\section{Tulokset ja tulosten tarkastelu}

Sovellusta avattaessa kuukausinäkymäksi tulee automaattisesti kuluvan kuukauden näkymä ja työkalu muistuttaa erillisessä ikkunassa seuraavan viikon ajalle merkityt tapahtumat. TTS:n sivuilta ladatun vuosikellon kuukausikalenterit ovat tyhjiä. Ennen työkalun hyödyntämistä käyttäjän on määriteltävä ja sijoitettava oman tilansa muistettavat työt ja tapahtumat kuukausikalentereihin. Tämän jälkeen työkalua suositellaan käytettävän säännöllisesti ja päivitettävän kalenterien merkintöjä tarpeen mukaan. Ennen tiedoston sulkemista se on syytä tallentaa omalle tietokoneelle, jolloin myös kalentereihin tehdyt muutokset tallentuvat tiedostoon.

\section{Tapahtumien syöttö kalentereihin}

Kalentereihin voi lisätä tapahtumia kolmella tavalla. Ensinnäkin päiväkenttiin voi kirjata tapahtuman normaalein Excel-toiminnoin. Toiseksi yksittäisiä tapahtumia voi viedä kalenteriin syöttölomakkeella. Syöttölomake on tarkoitettu erityisesti epäsäännöllisten tapahtumien lisäämiseen kalenteriin. Yksittäisten tapahtumien syöttölomakkeessa tapahtumia voi valita pudotusvalikosta tai kenttiin voi syöttää omia tapahtumia. Kalenterinäkymän luettavuuden säilyttämiseksi tapahtuma on syytä merkitä mahdollisimman lyhyenä (maksimissaan 34 merkkiä). Lisätiedot -kenttään voi kirjoittaa pidempiä selityksiä ja lisätietoja tapahtumasta. Lisätiedot näkyvät kalenterinäkymässä Excel-kommenttina ja ne saadaan näkyviin viemällä hiiren osoitin solun oikeassa yläkulmassa olevan punaisen lipun päälle. Jos valitsee tapahtuman pudotusvalikosta, lisätietokenttään tulee kyseisen tapahtumaan liittyvät oletuksena olevat lisätiedot. Päivämäärän valinnan jälkeen tapahtuma viedään kalenteriin kyseisen tapahtumarivin lopussa olevaa OK -painiketta painamalla.

Kolmas tapa viedä tapahtumia kalenteriin on määritellä kaikki hankkeessa määritellyn tehtävälistan tapahtumat ja niiden päivämäärät ja toistuvuus samaan tauluun, josta ohjelma vie ne yhdellä klikkauksella kaikkiin kuukausikalentereihin. Säännöllisesti toistuviin tapahtumiin toistuvuudeksi voi määritellä kerran viikossa, joka toinen viikko, kerran kuukaudessa, joka toinen kuukausi, kaksi kertaa vuodessa, kerran vuodessa tai joka toinen vuosi. Edellä mainituista vaihtoehdoista käyttäjän pitää valita kyseiseen tapahtumaan parhaiten sopiva vaihtoehto. Epäsäännöllisesti toistuvat tapahtumat pitää merkitä kalentereihin yksittäisinä tapahtumina.

Toistuvista tapahtumista käyttäjä voi määritellä itse tapahtuman tärkeyden. Tärkeysaste on kolmiportainen ja se valitaan pudotusvalikosta. Eri tärkeysasteiset tapahtumat erottuvat toisistaan kalentereissa ja tapahtumalistauksessa.

Viimeisenä sarakkeena toistuvien tapahtumien syöttötaulussa on "Vuosikello"-sarake, jolla määritellään kyseisen rivin tapahtuman näkyvyys vuosikello-näkymässä. Käyttäjän tähän sarakkeeseen punaisella merkitsemät tapahtumat viedään haluttaessa vuosikello-näkymään.

\section{Tapahtumien poisto kalentereista}

Kalentereista voi poistaa merkintöjä kolmella eri tavalla. Ensinnäkin kuukausikalenterista voi poistaa tiettyyn päivään/päiviin tehdyt merkinnät maalaamalla solualue ja tyhjentämällä sen sisältö normaalein Excel-toiminnoin. Aktiivisena olevan kuukauden kaikki tapahtumat voi poistaa klikkaamalla taulun yläosassa olevaa "Tyhjennä kalenteri"-painiketta. Kaikkien kalentereiden kaikki merkinnät voi poistaa klikkaamalla aloitussivulla olevaa "Poista kaikki tapahtumat kalentereista" -painiketta. Poistotoiminnoissa kysytään käyttäjältä varmistus poistoon lukuun ottamatta Excelin normaalia solualueen tyhjennystä.

\section{Kalenteritapahtumien listaus}

Työkaluun kehitettiin toiminto, jolla kalentereihin tehdyt merkinnät, niihin liittyvät lisätiedot ja päivämäärät listautuvat allekkain omaan "Listaus"-tauluun. Listaustauluun pääsee aloitussivulta klikkaamalla "Listaa kalentereissa olevat tapahtumat"-painiketta jolloin samalla kyseinen lista päivittyy. Menneeseen aikaan sijoittuvat tapahtumat erottuvat listasta harmaalla pohjavärillä. Listausta voi lajitella ja suodattaa Excel-toiminnoin ja esimerkiksi tulostaa se kokonaisuudessaan tai suodatettuna paperille. Listauksen tai halutun osan siitä voi myös helposti lähettää sähköpostilla eteenpäin, jolloin se on nähtävissä sähköisenä myös muissa kuin varsinaisessa sovelluksessa. 


\section{Tehtävälistan luonti ja muokkaus}

Hankkeessa laadittiin maatalousyrittäjien tärkeimpien töiden organisointiin ja johtamiseen liittyvä tehtävälista. Listan runko laadittiin TTS:ssa ja sen täydentämisessä käytettiin apuna sekä ProAgrian asiantuntijoita että työkalun testausvaiheen maatalousyrittäjiä. Työkalun lopulliseen versioon tuli 94 kohdan tehtävälista. Tätä tehtävälistaa käyttäjä voi itse muokata ja myös lisätä uusia kohtia listaan.

Tehtävälistan sisältö vaihtelee paljon tuotantosuunnan mukaan. Tässä hankkeessa laadittiin yksi työkalu, jossa eri tuotantosuuntiin kuuluvat tehtävät erottuvat tehtävälistassa eri pohjavälillä. Näin esimerkiksi kasvinviljelytila voi helposti hypätä yli kotieläintuotantoon liittyvät osat tehtävälistassa.

\section{Vuosikello-näkymä}

Työkalu sisältää kuukausi-näkymien lisäksi vuosikello-näkymän, johon voi sijoittaa tärkeimpiä maatilan johtamiseen liittyviä vuosittaisia tapahtumia kuukausijaolla. Vuosikello-näkymään voi sijoittaa korkeintaan kaksi merkintää kuukautta kohti. Vuosikellon kuukausitapahtumiksi voi valita joko oletustehtävät tai tehtävälistasta käyttäjän valitsemat tärkeimmät tapahtumat. Vuosikello-näkymä on visuaalinen tapa esittää maatilan johtamiseen liittyvien tärkeiden tapahtumien karkeaa ajoittumista.

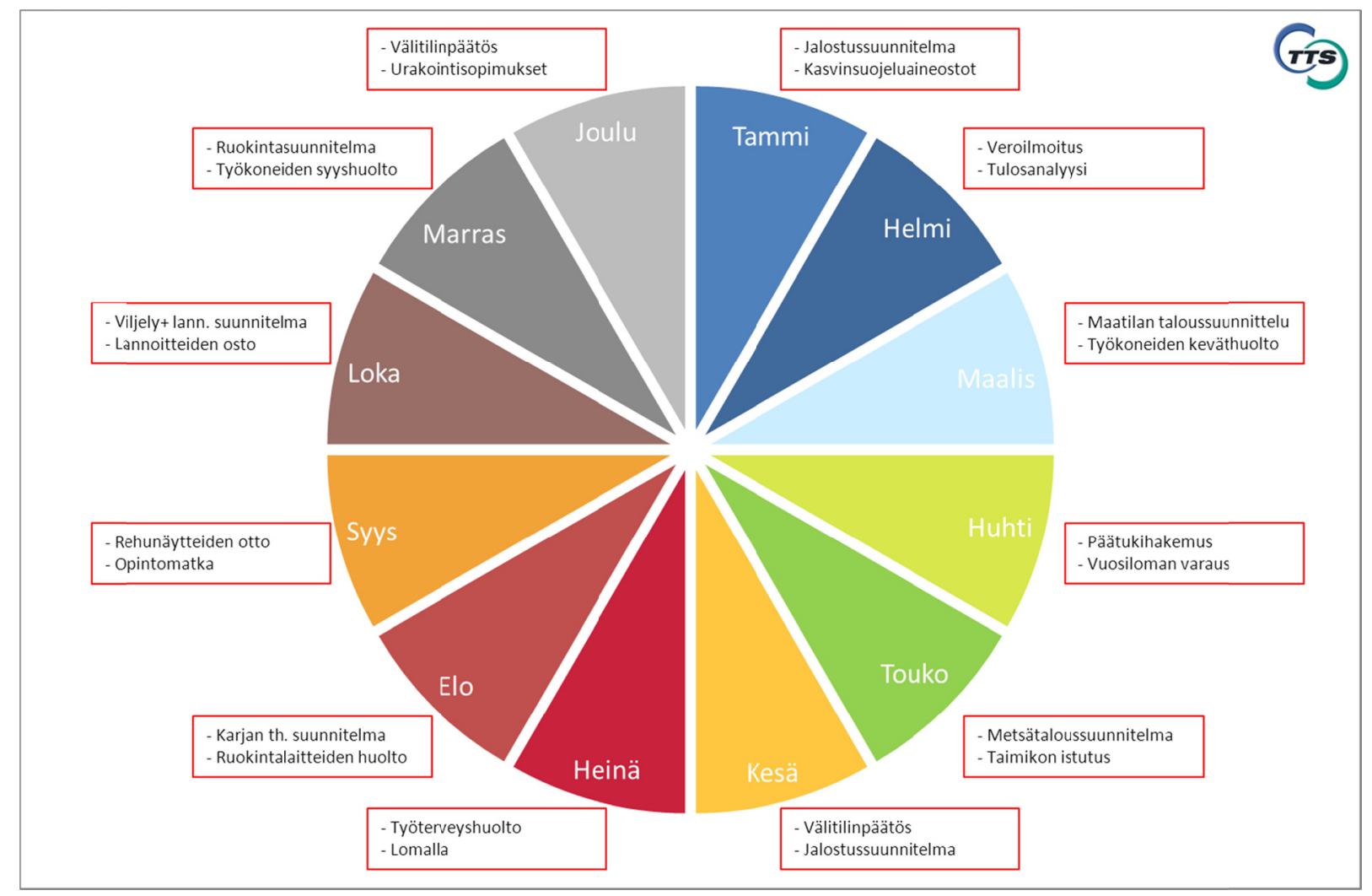

Kuva 2. Työkalu sisältää kuukausi-näkymien lisäksi vuosikello-näkymän, johon voi sijoittaa tärkeimpiä maatilan johtamiseen liittyviä vuosittaisia tapahtumia kuukausijaolla.

\section{Johtopäätökset}

Maatilan työmäärän hallintaa ja töiden organisointia kehittävissä hankkeissa keskitytään yleensä varsinaisiin päivittäisiin ja kausittaisiin tuotantotöihin, joihin kuluu valtaosa tilan kokonaistyönmenekistä. Tässä hankkeessa keskityttiin muihin tuotannon pyörittämiseen liittyviin töihin, joiden osuus tilan kokonaistyönmenekistä vaihtelee muun muassa tilan tuotantosuunnan ja koon mukaan. Näiden töiden ennakointi, muistaminen ja oikea-aikaisuus vaikuttavat kuitenkin merkittävästi niin tilan kokonaistyömäärän hallintaan ja yrittäjän jaksamiseen kuin myös tilan taloudelliseen tulokseen.

Hankkeessa kehitetty maatalousyrittäjän vuosikello on vapaasti ladattavissa TTS:n nettisivuilta. Työkalu on tarkoitettu ensisijaisesti eri tuotantosuuntien maatalousyrittäjien käyttöön. Työkaluun liittyviä kalenteritoimintoja voi kuitenkin hyödyntää myös muussa yritystoiminnassa samoin kuin yksi- 
tyistalouksissa arjen hallinnassa. Työkaluun liittyvä tehtävälista on muokattavissa ja täydennettävissä, joten käyttäjä pystyy räätälöimään työkalun sisältöä tietyissä määrin omiin tarpeisiinsa.

Sivutuloksena hankkeessa syntyi monen asiantuntijan voimin laaja maatalousyritysten rutiinien ja päätöksentekoon liittyvien töiden ja tapahtumien tehtävälistaus. Tätä ainutlaatuista listausta voidaan hyödyntää muistilistan tavoin maatilan johtamisessa myös ilman varsinaista hankkeessa tuotettua asiantuntijasovellusta. Tehtävälistausta voidaan hyödyntää jatkossa muun muassa TTS:ssa ylläpidetyn maataloustyön standardiaikajärjestelmän kehittämisessä.

Työkalua pitää käyttää säännöllisesti, jotta siitä olisi käyttäjälleen hyötyä. Käytännössä tämä tarkoittaa sovelluksen avaamista tietokoneella vähintään kerran viikossa. Työkalun käyttöä rajoittaa se, että ohjelma vaatii tietokoneelta toimiakseen MS Windows -käyttöjärjestelmän ja MS cel -ohjelman. Tämä rajoitus voidaan jatkossa poistaa ohjelmoimalla työkalu itsenäiseksi ohjelmaksi.

Työkalun käytännön testauksessa tuli esille, että erityisesti harvemmin kuin viikoittain toistuvat tapahtumat vaativat apuvälineitä muistamiseen. Tiettyyn viikonpäivään sidotut viikoittaiset tapahtumat pysyvät sen sijaan hyvin mielessä. Kalentereihin on syytä merkitä yritystoiminnan kannalta vain tärkeät tapahtumat. Jos kalenteri on täynnä merkintöjä, ne voivat kokea "inflaation" ja todella tärkeät muistamiset saattavat jäädä huomaamatta. Täyteen merkitty kalenteri voi myös ahdistaa henkisesti.

Maatilayrityksen johtaminen vaatii taitoa, joka pääosin opitaan vasta maatilaa johdettaessa ja työtä tehden. Tämän takia johtamisen apuvälineitä tarvitsevat erityisesti nuoremmat viljelijät, joilla ei ole vielä vahvaa rutiinia asioiden hallinnasta. Nuorten viljelijöiden on myös erityisen tärkeää oppia alusta alkaen tekemään oikeita asioita oikein, etteivät tehottomat, huonot ja jopa vaaralliset työtavat ja -menetelmät pääse muodostumaan rutiineiksi.

Työkalun käytettävyyttä parantaisi huomattavasti kalenterien synkronointimahdollisuus matkapuhelimeen. Mikäli matkapuhelimeen saisi tuotua vuosikellosta tapahtumia ja toisaalta sillä pystyisi syöttämään uusia tapahtumia vuosikelloon, kalenterien käyttö ja tapahtumien päivitys olisi paljon nykyistä helpompaa. Markkinoilta löytyy joitain kaupallisia palveluita tähän tarkoitukseen ja niiden selvittäminen on aiheellista, mikäli työkalun käytettävyyttä halutaan jatkossa parantaa tähän suuntaan.

\section{Kiitokset}

Tämä maa- ja metsätalousministeriön maatilatalouden kehittämisrahaston rahoittama hanke toteutettiin yhteistyössä Savonia-ammattikorkeakoulun kanssa, jossa tehtiin hankkeen aihealuetta täydentävä ylemmän amk-tutkinnon opinnäytetyö (Tiikkainen ja Virkkunen 2010). Opinnäytetyön pohjalta laadittiin TTS:n tiedote (Tiikkainen ym. 2011). Kiitämme hankkeen rahoittajaa, aktiivista ohjausryhmää ja Savonia AMK:ta hedelmällisestä yhteistyöstä.

\section{Kirjallisuus}

Karttunen, J. \& Tuure, V-M. 2008. Töiden organisointi maatalousyrityksissä. TTS tutkimuksen tiedote 4/2008 (607). 1-8.

Suomen Gallup Elintarviketieto. 2005. Työhyvinvointi ja yhteistyön sekä työvoiman käyttöön liittyvät käytännöt nykyisin ja tulevaisuudessa maatiloilla -viljelijäkysely.

Suutarinen, J., Karttunen, J., Tuure, V-M., Rikkonen, P., Rautiainen, R., Louhelainen, K., Mattila, T. \& Pehkonen, A. 2008. Kestävän maatilatalouden työturvallisuuden, -hyvinvoinnin ja -terveyden muutostekijät ja tutkimusalan kehitystarpeet 2008-2015. Maa- ja elintarviketalouden tutkimuskeskus. Maa- ja elintarviketalous 127. Teknologia. $77 \mathrm{~s}$.

Tiikkainen, M. \& Virkkunen, M. 2011. Laajentavien nautatilojen tuotantorakennuksen rakennusprojektin vaiheistus ja johtaminen. Ylemmän amk-tutkinnon opinnäytetyö. Savonia-ammattikorkeakoulu. 78 s. Saatavilla: https://publications.theseus.fi/bitstream/handle/10024/26198/Tiikkainen_Mika_Virkkunen_Reijo.pdf?sequence= 1

Tiikkainen, M., Virkkunen, R., Paldanius, K., Karttunen, J. \& Kaila, E. 2011. Lypsykarjanavetan rakennusprojektin ja tuotannon laajentamisen johtaminen. TTS:n tiedote, Maataloustyö ja tuottavuus 3/2011 (630). $8 \mathrm{~s}$.

Tuure, V-M, Karttunen, J., Leppälä, J., Sinisalo, A. \& Kaila, E. 2008. Maatilan ajankäytön hallinta. Teoksessa: Rikkonen, P., Harmoinen, T. \& Teräväinen, H. (toim.). Maatilayrityksen menestystekijät. ProAgria Maaseutukeskusten Liitto. Tieto Tuottamaan 123: 53-63. 